\title{
月三年三十二治 明
}

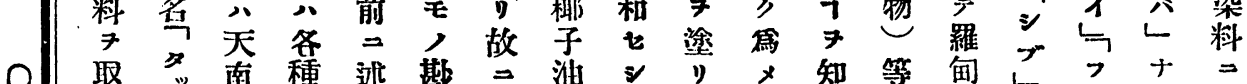

拍 ル カ 星





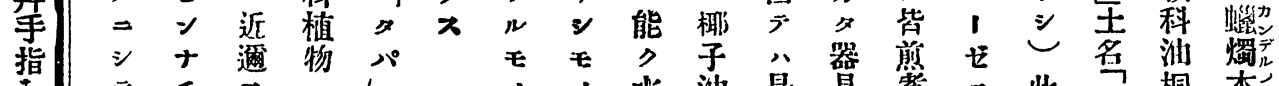

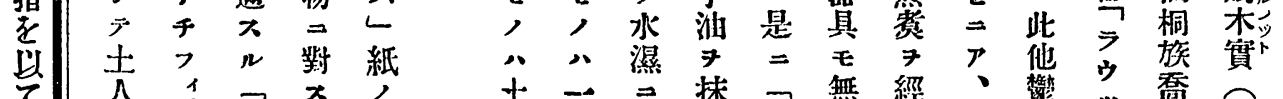

ᄂ.

賣 往

す夺加各=

る 之正 ᄂ $\Rightarrow$ 供

の 7 , 料屬

遭栽ナ：ル

風培 》 宿

附 り 即根其

目 而其 $=$ 七

У根蓄 ル

志種罣布 カ

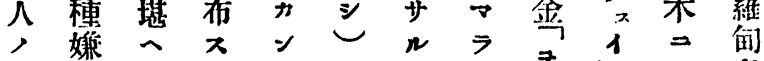

身蕜我

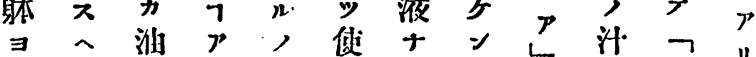



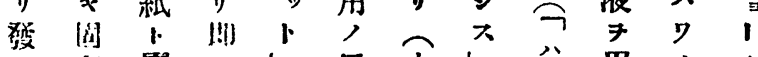

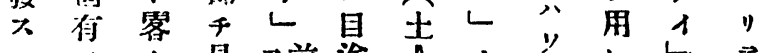

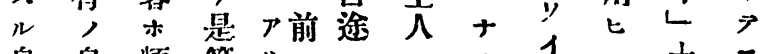

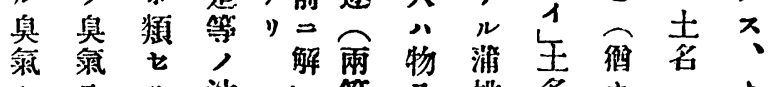



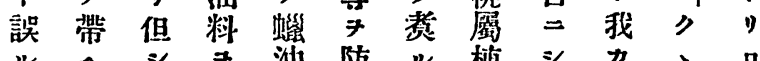

此 ”糊羅王占

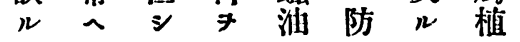

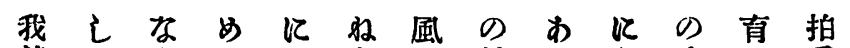
替 あるて あ市な見る古自手

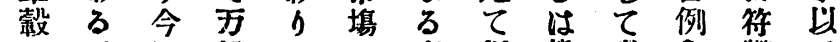
の 以に般てを事以皆現を牒て 下是各のは箽明て人に列を契 志等地貨賣す 5 怪 の 条舉 以 約

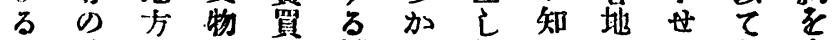

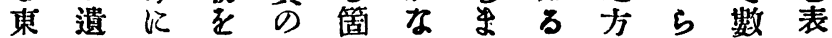

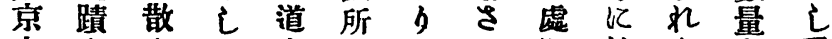

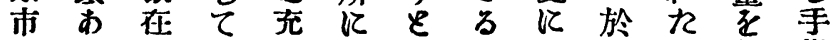

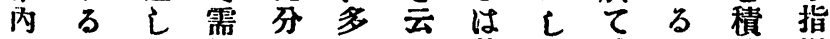

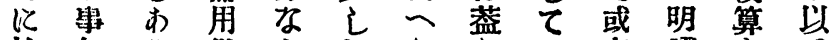

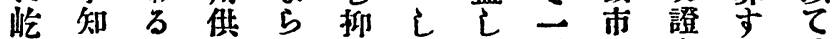
然る 何給す此且其種幫卓る 或

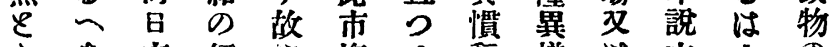

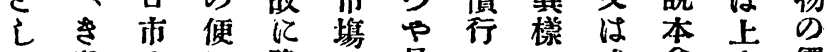

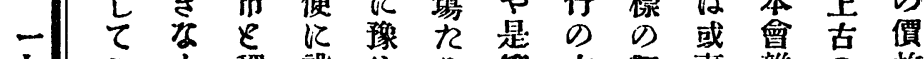



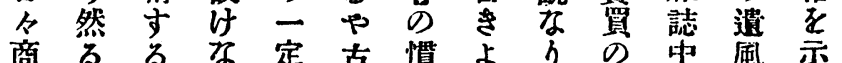

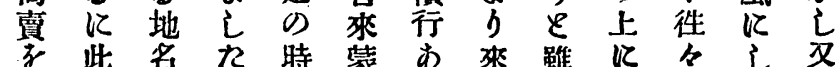

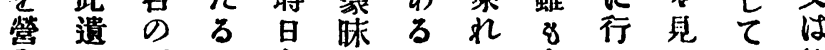

み風現8方のはる重はる 其彼 あか 存の 定特蔇遗人记處事の

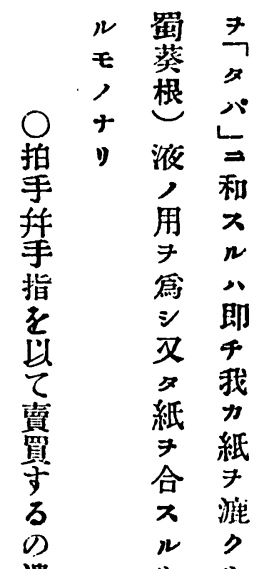

遺 牛

麥然 ᄀ

数古

留》

代 ᄂ

用黄 
號入十四第誌雑會舉類八京東

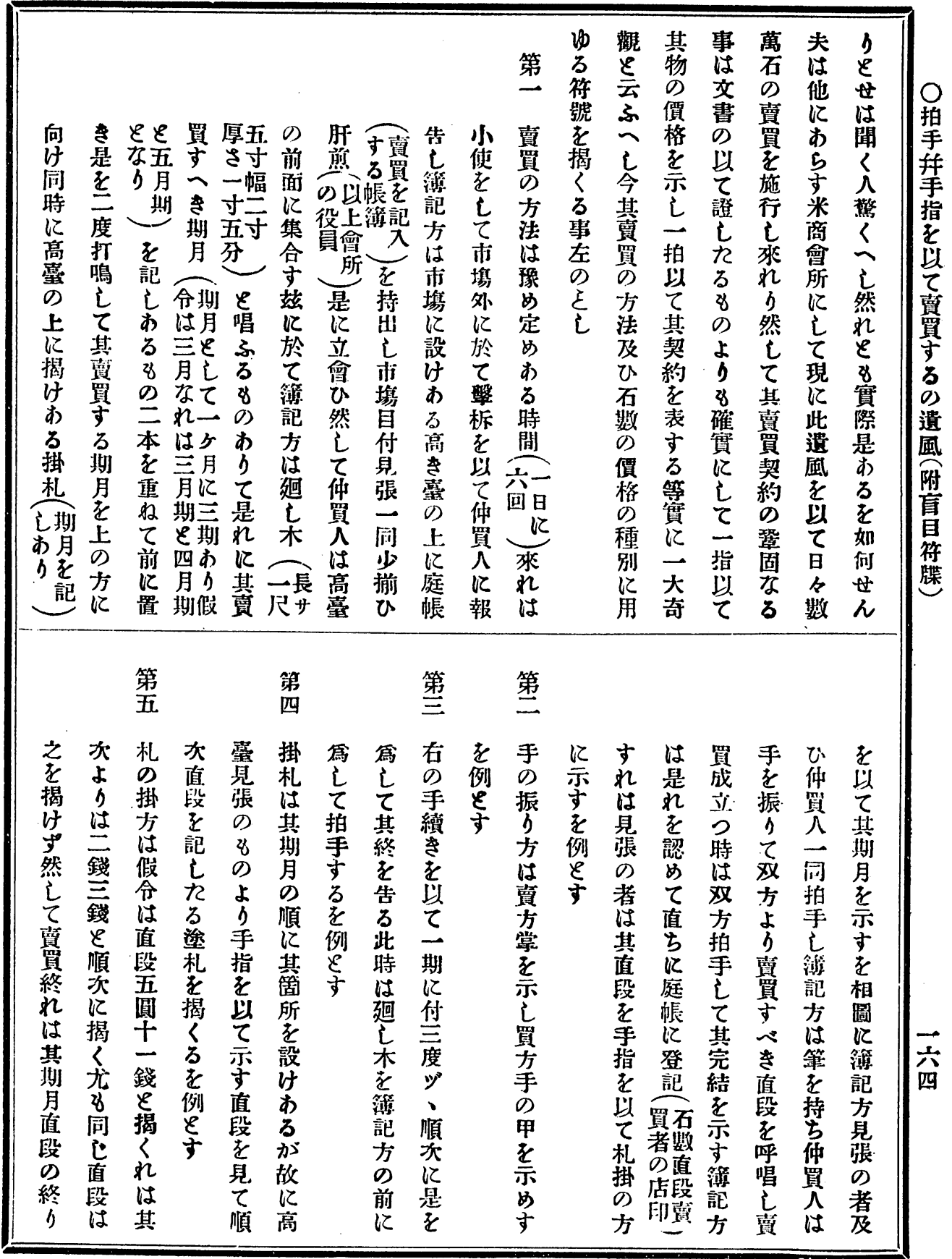




\section{月三年三十二治 明}

O

報

万是 租

乙 $八$ 別

步 一 昰

万查

成守

立 万

了時

小 は

啓左

に

用 符

10 牒

五を

に角

至 功

第

第

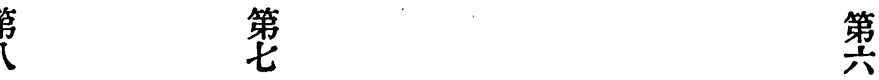

田石劣柇 の 期

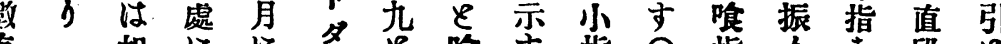

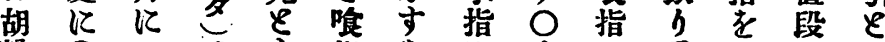

粉出よを卞指を迄中を手战を記

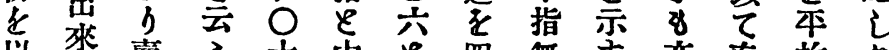





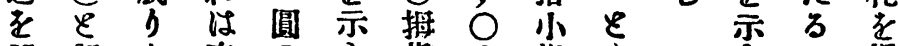
記記立直 の す指全指す 告8 揭

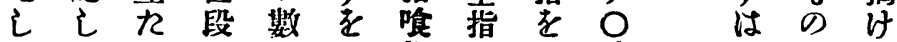

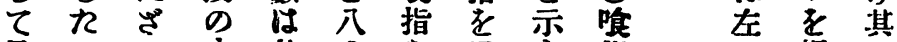
見る る 土其を先示文指揭次

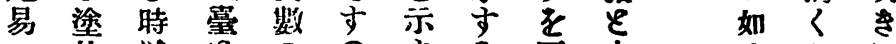


ら基 之揭期



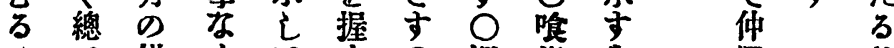

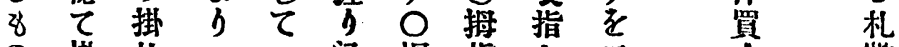
の掛札込拇指よ三

人

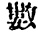

但前 心務、 1

今 $=$ 神 $x \geq 1, n 千$ 部蒂

二生聖居ン亣テ公學國

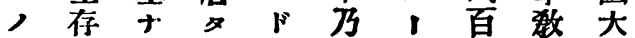

木女ッルン伊ブ公室學

乃り性モ上,

伊即質, 呼

八千尗ブノ木年ルミ

發今示推 身被乃

見 7 考分覆伊開

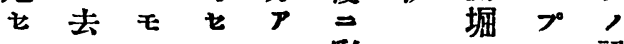



睢子、少色州明

二三如如广 女 $n$ 三 書

》干头何》穴 1



一、白人,

宍 八年婦レブノ

五 $匚$ 人 ハ 府示

沙,

プ 紀, 大 如

卜元或寺》

學 $\pi$ 少

$\Rightarrow$ 百 形 役 7

從年狱

墓境

以

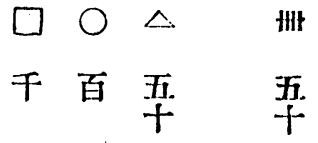

報

是是是至是

は 川

于百五五十

上 $\infty \omega+1$

數 數 の む

に数成

用用江立

化讬用步

鞂

$=$

用

W

横 